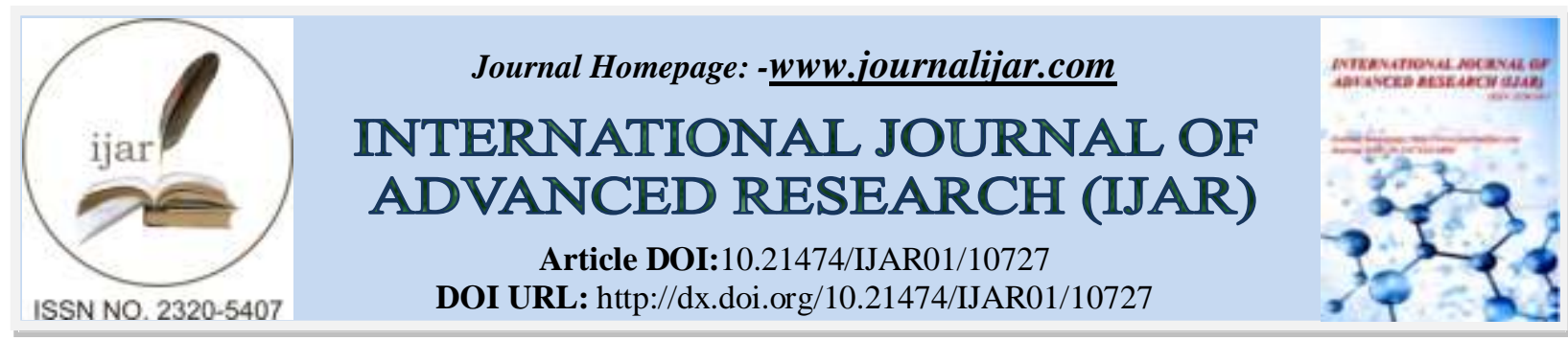

RESEARCH ARTICLE

\title{
EFFECT OF AMENDMENT RESIDUE ON SOIL CHEMICAL PROPERTIES, YIELD POTENTIAL AND PROTEIN CONTENT IN SOYBEAN (Glycine Max (L.) MERR)
}

\section{Cut Risna Gusnita ${ }^{1}$, Helmi $^{2}$, Syakur $^{2}$, Sabaruddin $^{3}$ and Desi Badriana ${ }^{3}$}

1. Master Student of Agroecotechnology, Faculty of Agriculture UniversitasSyiah Kuala, Banda Aceh, Indonesia 23111.

2. Department of Soil Science, Faculty of Agriculture UniversitasSyiah Kuala, Banda Aceh, Indonesia 23111.

3. Department of Agrotechnology, Faculty of Agriculture UniversitasSyiah Kuala, Banda Aceh, Indonesia 23111.

\section{Manuscript Info}

Manuscript History

Received: 25 January 2020

Final Accepted: 27 February 2020

Published: March 2020

Key words:-

Soil Amendment, Chemical Properties, Protein, Yield Potential

\begin{abstract}
Biochar rice husks and cow manure as soil amendment have the potential to improve soil chemical properties such as soil $\mathrm{pH}, \mathrm{CEC}$, and several compounds such as $\mathrm{C}$-organic, $\mathrm{N}$-total and can fertilize the soil. This research is the third planting season, continued from the previous two planting seasons. The purpose of this study was to determine the effectof residual soil amendment in the third planting season on soil chemical properties, yield potential and protein content of soybean seed. From this research, the residue of soil amendment in the first planting season and the addition in the second planting season showed values that were not much different in each treatment both from the chemical nature of the soil and protein content. Soil pH, P-available and CEC tends to increase in residual cow manure 20 tons ha ${ }^{-1}$ and 10 tons $\mathrm{ha}^{-1}$ but not significant. Likewise with the potential for large yields in cow manure residues of 20 tons $\mathrm{ha}^{-1}$, another case with the highest crude protein content obtained in the control (R1) (without the soil amendment or fertilizer).
\end{abstract}

Copy Right, IJAR, 2020,. All rights reserved.

\section{Introduction:-}

The prospect of increasing dryland productivity as a food provider is huge. Around 76,21 million hectares of dry land in Indonesia are classified as suitable for annual and annual crops (Mulyani and Agus, 2006). However, in general the quality of dry land in Indonesia is relatively low, resulting in low productivity of land and plants. Restoration of dry land becomes a priority if the land is to be intensively managed. One of the efforts is to accelerate the restoration of soil quality by using various soil amendment ingredients that are easily available and can last a long time in the soil or have relatively long effects. The addition of organic material as a soil amendment is another alternative that is considered to be more beneficial both in terms of technical, economic, social and beneficial to the environment (Syamsuddin et al., 2016). The use of biocharsoil amendment and cow manure can influence the increase in growth and yield of plants, this is in accordance with what was said by Zhu et al (2014), the effect of biochar administration increases plant growth through reducing Al toxicity and P. efficiency. In addition, Gani( 2009) also said that one of the raw materials for biochar came from burning rice husks. Rice husk is agricultural waste that can fertilize the soil and can be used as an alternative for soil management. Biochar has the potential to improve soybean production through increased carbon content in the soil.Soybean (Glycine max (L.) Merrill) is an important commodity because the level of Indonesian soybean consumption is quite high. This is because soy is one 
of the sources of vegetable protein for diversification in order to support the national food security program (Hasanuddinet al., 2005). The crude protein content in plants can be increased due to the presence of large amounts of soil fauna such as earthworms which can play a role in the removal of deciduous leaves so as to increase soil nitrogen. Another factor that can increase levels of crude protein in plants is the ability of plants to absorb nitrogen (Wilson et al., 1990). Plants grown under shade have lower crude fiber content due to an increase in N elements. Crude protein has the understanding of the amount of nitrogen $(\mathrm{N})$ contained in feed ingredients then multiplied by a protein factor of 6,25\% (plant-based feed) or 5,56\% (animal feed). Figures 6,25\% and 5,56\% are obtained assuming that protein contains $16 \%$ nitrogen (Fathul, 2014).

This research is the third planting season from the previous research, namely in the first planting season (water spinach plants), the second planting season (corn) and in the third planting season using soy plants planted on land with residual soil amendment in the previous planting season, to see how much influence the residual soil amendment has on the chemical properties of the soil, and is there any effect on the yield potential and protein content of the soybeans. This research is expected to add insight into the effect of soil amendments residues on soil chemical properties, yield potential and protein content in soybean plants.

\section{Method:-}

The research was conducted at the Experimental Garden of the Faculty of Agriculture, Syiah Kuala University at coordinates $05^{\circ} 17^{\prime} 05.2$ "N and $95^{\circ} 28^{\prime} 13.1^{\prime \prime} \mathrm{E}$, analysis of soil chemical properties was carried out at the Soil and Plant Laboratory of the Aceh Agricultural Technology Assessment Center and the Soil Chemical Laboratory of the Faculty of Agriculture Syiah Kuala University, and analysis of protein content was carried out at the Laboratory of Animal Nutrition Science, Department of Animal Husbandry, Faculty of Agriculture, Syiah Kuala University.

The materials used are NPK phonska fertilizer, Urea and $\mathrm{KCl}$, Rhizobium sp. (Agrisoy) and Dena 1 variety soybean seed, as well as materials used for chemical analysis of soil and protein in the Laboratory. The tools used are scales, soil drill and other laboratory tools that support analysis. The design used in this study was a non-factorial randomized block design with 2 replications consisting of 30 plots and 15 treatments.

This study is a continuation of previous studies, namely in the first planting season the application of soil amendment to water spinach plants and in the second planting season, the effect of residues and the addition of soil amendment in corn plants. The combination of treatments in the first and second growing seasons can be seen in Table 1.

Table 1:- Combination of the First and Second Season of Soil amendment Treatment.

\begin{tabular}{|c|c|c|c|}
\hline No & Treatment & $\begin{array}{l}\text { Residue Dose of Soil amendment First } \\
\text { Planting Period (Kale) }\end{array}$ & $\begin{array}{l}\text { Residue Dose of Soil amendment Second } \\
\text { Planting Period (Corn) }\end{array}$ \\
\hline 1 & $\mathrm{R} 1$ & Control (NPK $0 \%)$ & \\
\hline 2 & R2 & Control $(\mathrm{N}$ and $\mathrm{K})$ & \\
\hline 3 & R3 & Control (NPK $50 \%$ Recommendation) & \\
\hline 4 & $\mathrm{R} 4$ & $\begin{array}{l}\text { Biochar rice husk } 2,5 \text { ton } \mathrm{ha}^{-1}+\mathrm{NPK} 0 \\
\%\end{array}$ & Biochar rice husk 10 ton $\mathrm{ha}^{-1}+\mathrm{NPK} 0 \%$ \\
\hline 5 & $\mathrm{R} 5$ & Biochar rice husk 2,5 ton $\mathrm{ha}^{-1}+\mathrm{N}$ and $\mathrm{K}$ & Biochar rice husk 10 ton $\mathrm{ha}^{-1}+\mathrm{N}$ and $\mathrm{K}$ \\
\hline 6 & R6 & $\begin{array}{l}\text { Biochar rice husk } 2,5 \text { ton } \mathrm{ha}^{-1}+\mathrm{NPK} 50 \\
\% \text { Recommendation }\end{array}$ & $\begin{array}{l}\text { Biochar rice husk } 10 \text { ton } \mathrm{ha}^{-1}+\text { NPK } 50 \\
\% \text { Recommendation }\end{array}$ \\
\hline 7 & R7 & Biochar rice husk 5 ton ha $^{-1}+$ NPK $0 \%$ & \\
\hline 8 & R8 & Biochar rice husk 5 ton $\mathrm{ha}^{-1}+\mathrm{N}$ and $\mathrm{K}$ & \\
\hline 9 & R9 & $\begin{array}{l}\text { Biochar rice husk } 5 \text { ton } \text { ha }^{-1}+\text { NPK } 50 \% \\
\text { Recommendation }\end{array}$ & \\
\hline 10 & R10 & Cow manure 2,5 ton $^{-1}+$ NPK $0 \%$ & Cow manure 10 ton $\mathrm{ha}^{-1}+$ NPK $0 \%$ \\
\hline 11 & R11 & Cow manure 2,5 ton $\mathrm{ha}^{-1}+\mathrm{N}$ and $\mathrm{K}$ & Cow manure 10 ton $\mathrm{ha}^{-1}+\mathrm{N}$ and $\mathrm{K}$ \\
\hline 12 & $\mathrm{R} 12$ & $\begin{array}{l}\text { Cow manure } 2,5 \text { ton } \mathrm{ha}^{-1}+\mathrm{NPK} 50 \% \\
\text { Recommendation }\end{array}$ & $\begin{array}{l}\text { Cow manure } 10 \text { ton } \mathrm{ha}^{-1}+\mathrm{NPK} 50 \% \\
\text { Recommendation }\end{array}$ \\
\hline 13 & R13 & Cow manure 5 ton ha $^{-1}+$ NPK $0 \%$ & Cow manure 20 ton $^{-1}+$ NPK $0 \%$ \\
\hline
\end{tabular}




\begin{tabular}{|l|l|l|l|}
\hline 14 & R14 & Cow manure 5 ton $\mathrm{ha}^{-1}+\mathrm{N}$ and K & Cow manure 20 ton $\mathrm{ha}^{-1}+\mathrm{N}$ and K \\
\hline 15 & R15 & $\begin{array}{l}\text { Cow manure 5 ton } \mathrm{ha}^{-1}+\mathrm{NPK} \mathrm{50 \%} \\
\text { Recommendation }\end{array}$ & $\begin{array}{l}\text { Cow manure 20 ton } \mathrm{ha}^{-1}+\mathrm{NPK} 50 \% \\
\text { Recommendation }\end{array}$ \\
\hline
\end{tabular}

Soil sampling is done twice, namely before planting (initial soil sample) and postharvest. The technique of soil sampling is by taking three points in each experimental plot, then mixed and stirring evenly for each plot. Soil sampling is taken at a depth of $0-30 \mathrm{~cm}$. The parameters observed included $\mathrm{pH}\left(\mathrm{H}_{2} \mathrm{O}\right)$ (Electrometric), C-organic (Walklay and Black), N-total (Kjeldahl), P-available (Bray II), CEC (1 N Extract $\left(\mathrm{NH}_{4} \mathrm{O}\right.$ Ac)) and C:N ratio(Kjeldahl). In addition to the chemical properties of the soil this study also looked at the protein content of soybean seed by taking fresh soybean yields of 20 grams for analysis using the Kjeldahl method.

\section{Results and Discussion:- Soil Chemical Properties: \\ Soil pH:}

Acid soils have low $\mathrm{pH}$ values or high $\mathrm{H}^{+}$ion levels. But on the contrary, alkaline soils have high $\mathrm{pH}$ values or low $\mathrm{H}^{+}$ion levels. If the $\mathrm{H}^{+}$and $\mathrm{OH}^{-}$contents are the same, the soil reacts neutrally (Hardjowigeno, 2003). According to Kartikaet al., (2018) the application of biochar increases soil pH but does not affect cation exchange capacity (CEC), and the availability of major soil nutrients.

The results of the analysis of soil $\mathrm{pH}$ in the third growing season from the residues of soil amendment given in the first and second growing seasons can be seen in Table 2.

Table 2:- Average Soil pH effects of Soil amendment Residues at the Third Planting Period.

\begin{tabular}{|c|c|}
\hline Treatment & soil $\mathrm{pH}$ \\
\hline R1 (Control (NPK $0 \%)$ ) & $7,0 \mathrm{~cd}$ \\
\hline $\mathrm{R} 2($ Control $(\mathrm{N}$ and $\mathrm{K}))$ & $6,6 \mathrm{ab}$ \\
\hline R3 (Control (NPK 50\% recommendation)) & $6,8 \mathrm{abc}$ \\
\hline R4 (Biochar rice husk10 ton ha $^{-1}+$ NPK $\left.0 \%\right)$ & $6,8 \mathrm{abc}$ \\
\hline R5 (Biochar rice husk10 ton $\mathrm{ha}^{-1}+\mathrm{N}$ and $\left.\mathrm{K}\right)$ & 6,9 abcd \\
\hline R6 (Biochar rice husk10 ton ha $^{-1}+$ NPK $50 \%$ recommendation) & $6,6 \mathrm{a}$ \\
\hline R7 (Biochar rice husk 5 ton ha $^{-1}+$ NPK $\left.0 \%\right)$ & $7,0 \mathrm{~cd}$ \\
\hline R8 (Biochar rice husk 5 ton $\mathrm{ha}^{-1}+\mathrm{N}$ and $\mathrm{K}$ ) & 6,9 abcd \\
\hline R9 (Biochar rice husk 5 ton ha $^{-1}+$ NPK $50 \%$ recommendation) & 6,9 abcd \\
\hline R10 (Cow manure10 ton ha ${ }^{-1}+$ NPK $\left.0 \%\right)$ & $6,8 \mathrm{abc}$ \\
\hline R11 (Cow manure10 ton ha ${ }^{-1}+\mathrm{N}$ and $\left.\mathrm{K}\right)$ & $7,0 \mathrm{bcd}$ \\
\hline R12 (Cow manure10 ton $\mathrm{ha}^{-1}+$ NPK $50 \%$ recommendation) & $7,2 \mathrm{~d}$ \\
\hline R13 (Cow manure20 ton $\mathrm{ha}^{-1}+$ NPK $\left.0 \%\right)$ & $7,0 \mathrm{~cd}$ \\
\hline R14 (Cow manure20 ton ha $^{-1}+\mathrm{N}$ and $\left.\mathrm{K}\right)$ & $7,2 \mathrm{~d}$ \\
\hline R15 (Cow manure20 ton ha $^{-1}+$ NPK 50\% recommendation) & 6,9 abcd \\
\hline
\end{tabular}

\section{Description:}

Numbers followed by the same letters in the same column are not significantly different at the 0,05 test level (DMRT)

Table 2 shows the soil $\mathrm{pH}$ values tend to be higher in the treatment residues of R12 and R14, both of these treatments are residues from cow manure with a dose of 10 tons $\mathrm{ha}^{-1}$ and 20 tons $\mathrm{ha}^{-1}$. Whereas the lowest in R2 control which was only given $\mathrm{N}$ and $\mathrm{K}$ fertilizer was 6,6. As in the results of Herlambanget al. (2019), soil amendment materials such as biochar and cow manure function to improve the physical and chemical properties of the soil such as soil $\mathrm{pH}$. Changing the characteristics will create a better soil environment so that soil nutrients will become more available for growth.

In addition to cow manure residues, residues from rice husk biochar can also raise soil $\mathrm{pH}$ from $\mathrm{pH}$ conditions in the second growing season which averaged 6,57 from all treatments. As explained in the study of Nisa (2010) soils treated with biochar treatment can increase the soil $\mathrm{pH}$ value from the initial condition of 6,78 to 7,40 or an increase of 9,14\% from the initial soil condition. Furthermore, Xieet al (2016) added that biochar works well in terms of increasing soil $\mathrm{pH}$ and soil organic carbon. Based on statistics, there is a significant difference in the effect of soil 
amendment residues on the $\mathrm{pH}$ value of the soil, but it is not significant, because based on the criteria for soil properties, all are in the neutral category.

\section{C-organic:}

Organic carbon in the soil has a role in maintaining soil fertility from various aspects both-physical, chemical and biological soil. In this study, the effects of two types of soil amendments, namely residues from biochar rice husks and cow manure, were given in the previous two planting seasons. The results of the $\mathrm{C}$-organic analysis in the third growing season from the residues of soil amendment given in the first and second growing seasons can be seen in Table 3.

Table 3:- Average C-organic effects of Soil amendment Residues at the Third Planting Period.

\begin{tabular}{|c|c|}
\hline Treatment & C-organic (\%) \\
\hline R1 (Control (NPK $0 \%)$ ) & 0,79 \\
\hline $\mathrm{R} 2$ (Control $(\mathrm{N}$ and $\mathrm{K}))$ & 0,70 \\
\hline R3 (Control (NPK $50 \%$ recommendation)) & 0,73 \\
\hline R4 (Biochar rice husk10 ton ha $^{-1}+$ NPK $0 \%$ ) & 0,64 \\
\hline $\mathrm{R} 5$ (Biochar rice husk10 ton $\mathrm{ha}^{-1}+\mathrm{N}$ and $\left.\mathrm{K}\right)$ & 0,53 \\
\hline R6 (Biochar rice husk10 ton $\mathrm{ha}^{-1}+\mathrm{NPK} 50 \%$ recommendation) & 0,55 \\
\hline R7 (Biochar rice husk 5 ton ha $^{-1}+$ NPK $0 \%$ ) & 0,57 \\
\hline $\mathrm{R} 8\left(\right.$ Biochar rice husk 5 ton $\mathrm{ha}^{-1}+\mathrm{N}$ and $\left.\mathrm{K}\right)$ & 0,72 \\
\hline R9 (Biochar rice husk 5 ton $\mathrm{ha}^{-1}+\mathrm{NPK} 50 \%$ recommendation) & 0,59 \\
\hline R10 (Cow manure10 ton ha $^{-1}+$ NPK $\left.0 \%\right)$ & 0,68 \\
\hline R11 (Cow manure10 ton $\mathrm{ha}^{-1}+\mathrm{N}$ and $\left.\mathrm{K}\right)$ & 0,67 \\
\hline R12 (Cow manure10 ton ha $^{-1}+$ NPK $50 \%$ recommendation) & 0,67 \\
\hline R13 (Cow manure20 ton ha $^{-1}+$ NPK $0 \%$ ) & 0,62 \\
\hline R14 (Cow manure20 ton ha $^{-1}+\mathrm{N}$ and $\left.\mathrm{K}\right)$ & 0,72 \\
\hline R15 (Cow manure20 ton ha $^{-1}+$ NPK 50\% recommendation) & 0,67 \\
\hline
\end{tabular}

Table 3 above shows the results of the C-organic analysis on the study area very low criteria it is at a value $<1 \%$. This shows that the application of biocharsoil amendment to rice husks and cow manure has not been able to increase the soil organic carbon content in the third growing season, allegedly because the soil amendment, especially biochar, takes a long time to decompose in the soil. As stated by Gani (2009), another function of giving biochar as a soil amendment is being able to store carbon stable for thousands of years by immersing it in the soil. Furthermore, the results of the research Salawatiet al (2016) confirmed the function of rice husk biochar, namely the higher the dose of rice husk biochar given soil organic $\mathrm{C}$ content also increased consistently as well as the biochar fineness, the finer the biochar the higher the soil organic $\mathrm{C}$ content.

\section{Total Nitrogen:}

Nitrogen fertilization is needed by plants, this is because nitrogen is only absorbed in the form of anion nitrate $\left(\mathrm{NO}_{3}{ }^{-}\right.$ ) or ammonium cation $\left(\mathrm{NH}_{4}{ }^{+}\right)$, but the ammonium cation is very quickly oxidized to nitrate by bacteria in the soil, while nutrients in the anion form will be easy washed by negative soil particles and organic matter, making $\mathrm{N}$ difficult to be available to plants (Lakitan, 2012).

The results of the analysis of total $\mathrm{N}$ soil in the third planting season from the residual soil amendment given in the first and second growing season can be seen in Table 4.

In Table 4 shows the total $\mathrm{N}$ content is not statistically different, when viewed based on the criteria of soil properties, the condition of this soil is almost entirely at very low criteria if it is at a value $<0,10 \%$. The effect of the residue in the third planting season can significantly increase the total nitrogen value of the soil both without addition of doses or by adding a dose of soil amendment from the total $\mathrm{N}$ value of the soil in the initial conditions of the land which is $0,05 \%$. Rahmi and Biantary research (2014) states that vegetation that grows above the ground and its decomposition rate are factors that cause changes in N content in the soil. Furthermore Singh et al (2018) stated that the application of biochar made from rice husk can also significantly increase soil $\mathrm{N}, \mathrm{P}$ and $\mathrm{C}$ content. The same thing was conveyed by Yunilasari (2019), the total N-content in the soil increased, but the amount was 
still in a very low criterion, the low increase in the total N-total soil could be due to adsorption by biochar and also absorption by plants better.

Table 4:- Average N-total effects of Soil amendment Residues at the Third Planting Period.

\begin{tabular}{|c|c|}
\hline Treatment & N-total $(\%)$ \\
\hline R1 (Control (NPK $0 \%)$ ) & 0,12 \\
\hline $\mathrm{R} 2($ Control $(\mathrm{N}$ and $\mathrm{K}))$ & 0,09 \\
\hline R3 (Control (NPK $50 \%$ recommendation)) & 0,10 \\
\hline R4 (Biochar rice husk10 ton ha $^{-1}+$ NPK $0 \%$ ) & 0,09 \\
\hline $\mathrm{R} 5$ (Biochar rice husk10 ton $\mathrm{ha}^{-1}+\mathrm{N}$ and $\left.\mathrm{K}\right)$ & 0,09 \\
\hline R6 (Biochar rice husk10 ton ha $^{-1}+$ NPK $50 \%$ recommendation) & 0,10 \\
\hline R7 (Biochar rice husk 5 ton ha $^{-1}+$ NPK $\left.0 \%\right)$ & 0,08 \\
\hline $\mathrm{R} 8\left(\right.$ Biochar rice husk 5 ton $\mathrm{ha}^{-1}+\mathrm{N}$ and $\left.\mathrm{K}\right)$ & 0,09 \\
\hline R9 (Biochar rice husk 5 ton ha $^{-1}+$ NPK $50 \%$ recommendation) & 0,09 \\
\hline R10 (Cow manure10 ton ha $^{-1}+$ NPK $\left.0 \%\right)$ & 0,09 \\
\hline R11 (Cow manure10 ton $\mathrm{ha}^{-1}+\mathrm{N}$ and $\mathrm{K}$ ) & 0,08 \\
\hline R12 (Cow manure10 ton ha $^{-1}+$ NPK $50 \%$ recommendation) & 0,07 \\
\hline R13 (Cow manure20 ton $\mathrm{ha}^{-1}+\mathrm{NPK} 0 \%$ ) & 0,07 \\
\hline R14 (Cow manure20 ton ha $^{-1}+\mathrm{N}$ and $\left.\mathrm{K}\right)$ & 0,09 \\
\hline R15 (Cow manure20 ton $\mathrm{ha}^{-1}+$ NPK 50\% recommendation) & 0,08 \\
\hline
\end{tabular}

\section{P Available:}

In addition to nitrogen, phosphorus nutrients (P) are also absolutely needed by plants. Yunilasari (2019) said, the amount of $\mathrm{P}$ in the soil is usually more than the amount of $\mathrm{N}$, however the $\mathrm{P}$ element is difficult to be absorbed by plants because it is difficult to dissolve and fixated by soil particles. The results of the $\mathrm{P}$ analysis are available in the third growing season from the residual soil amendment that has been given in the first and second growing seasons can be seen in Table 5 .

Table 5:- Average P available effects of Soil amendment Residues at the Third Planting Period.

\begin{tabular}{|c|c|}
\hline Treatment & $\mathrm{P}$ available(ppm) \\
\hline R1 (Control (NPK $0 \%))$ & $36,97 \mathrm{a}$ \\
\hline $\mathrm{R} 2(\mathrm{Control}(\mathrm{N}$ and $\mathrm{K}))$ & $38,26 \mathrm{ab}$ \\
\hline R3 (Control (NPK 50 \% recommendation)) & 41,17 bcde \\
\hline $\mathrm{R} 4$ (Biochar rice husk10 ton $\left.\mathrm{ha}^{-1}+\mathrm{NPK} 0 \%\right)$ & $38,20 \mathrm{ab}$ \\
\hline R5 (Biochar rice husk10 ton $\mathrm{ha}^{-1}+\mathrm{N}$ and $\mathrm{K}$ ) & $37,75 \mathrm{ab}$ \\
\hline R6 (Biochar rice husk10 ton $\mathrm{ha}^{-1}+$ NPK $50 \%$ recommendation) & 41,53 bcde \\
\hline $\mathrm{R} 7$ (Biochar rice husk 5 ton $\mathrm{ha}^{-1}+\mathrm{NPK} 0 \%$ ) & $38,50 \mathrm{abc}$ \\
\hline R8 (Biochar rice husk 5 ton $\mathrm{ha}^{-1}+\mathrm{N}$ and $\mathrm{K}$ ) & $39,49 \mathrm{abc}$ \\
\hline R9 (Biochar rice husk 5 ton ha $^{-1}+$ NPK $50 \%$ recommendation) & 43,77 ef \\
\hline R10 (Cow manure10 ton ha $^{-1}+$ NPK $\left.0 \%\right)$ & 42,28 cdef \\
\hline $\mathrm{R} 11\left(\mathrm{Cow}\right.$ manure10 ton $\mathrm{ha}^{-1}+\mathrm{N}$ and $\left.\mathrm{K}\right)$ & 40,78 abcde \\
\hline R12 (Cow manure10 ton ha $^{-1}+$ NPK $50 \%$ recommendation) & 43,66 def \\
\hline R13 (Cow manure20 ton ha ${ }^{-1}+$ NPK $\left.0 \%\right)$ & 39,79 abcd \\
\hline $\mathrm{R} 14$ (Cow manure20 ton $\mathrm{ha}^{-1}+\mathrm{N}$ and $\left.\mathrm{K}\right)$ & 40,60 abcde \\
\hline R15 (Cow manure20 ton ha $^{-1}+$ NPK 50\% recommendation) & $45,54 \mathrm{f}$ \\
\hline
\end{tabular}

Description: Numbers followed by the same letters in the same column are not significantly different at the 0,05 test level (DMRT)

Table 5 shows the value of $\mathrm{P}$ in the post-harvest soybean crop of the third growing season showing very high values based on the criteria of soil properties according to the Soil Research Institute (2009). Not only in the treatment given soil amendment, so also with controls R1, R2 and R3 which were not given soil amendment at all. The high available $\mathrm{P}$ value is also based on the initial state of the land before the study, the $\mathrm{P}$ content in the soil is already high at 28 ppm (Soil survey staff, 2014). Statistical test results showed a difference in the treatment of R15 which tends 
to be higher with the addition of soil amendment doses of cow manure from 5 tons ha ${ }^{-1}$ plus $50 \%$ NPK fertilizer recommendations in the first planting season to 20 tons ha ${ }^{-1}$ cow manure plus $50 \%$ NPK fertilizer recommendation with a value of $45,54 \mathrm{ppm}$, and the lowest is in the R1 control with a value of 36,97 ppm. In the study of Miet al (2018), it produced NPK fertilizer with organic soil amendment (cow manure) at soil depth of 0-10 cm showing the highest level of available $\mathrm{P}$ concentration.

In addition to cow manure, increasing the dose of rice husk soil amendment and rice husk biochar can also increase the $\mathrm{P}$ value available in the soil. As said by Liu et al (2017), that the administration of rice husk biochar can provide growth effects that are more suitable for soil bacteria and significantly increase the availability of soil phosphorus, biochar has a positive effect on phosphate solubilizing bacteria and contributes to an increase in phosphorus availability. Then, Panditet al (2018) also said that biochar as a soil amendment can significantly increase the content of available $\mathrm{P}$ in the soil.

\section{Cation Exchange Capacity (CEC):}

Soils with high organic matter content have a higher CEC, as well as younger soils with new weathering starting with soils with advanced weathering having a low CEC value (Tambunan, 2008). The results of the analysis of soil CEC in the third planting season from the provision of soil amendments in the first and second planting seasons can be seen in Table 6.

Table 6:- Average CECeffects of Soil amendment Residues at the Third Planting Period.

\begin{tabular}{|c|c|}
\hline Treatment & CEC (me $100 \mathrm{~g}^{-1}$ ) \\
\hline R1 (Control (NPK $0 \%)$ ) & 9,55 \\
\hline R2 (Control $(\mathrm{N}$ and $\mathrm{K}))$ & 10,98 \\
\hline R3 (Control (NPK $50 \%$ recommendation)) & 7,48 \\
\hline R4 (Biochar rice husk10 ton ha $^{-1}+$ NPK $0 \%$ ) & 8,18 \\
\hline R5 (Biochar rice husk10 ton $\mathrm{ha}^{-1}+\mathrm{N}$ and $\left.\mathrm{K}\right)$ & 9,18 \\
\hline R6 (Biochar rice husk10 ton ha $^{-1}+$ NPK $50 \%$ recommendation) & 9,13 \\
\hline R7 (Biochar rice husk 5 ton $\mathrm{ha}^{-1}+\mathrm{NPK} 0 \%$ ) & 10,65 \\
\hline $\mathrm{R} 8\left(\right.$ Biochar rice husk 5 ton $\mathrm{ha}^{-1}+\mathrm{N}$ and $\left.\mathrm{K}\right)$ & 11,15 \\
\hline R9 (Biochar rice husk 5 ton $\mathrm{ha}^{-1}+\mathrm{NPK} 50 \%$ recommendation) & 10,35 \\
\hline R10 (Cow manure10 ton ha $^{-1}+$ NPK $\left.0 \%\right)$ & 10,80 \\
\hline R11 (Cow manure10 ton $\mathrm{ha}^{-1}+\mathrm{N}$ and $\left.\mathrm{K}\right)$ & 10,85 \\
\hline R12 (Cow manure10 ton ha $^{-1}+$ NPK $50 \%$ recommendation) & 11,25 \\
\hline R13 (Cow manure20 ton ha $^{-1}+$ NPK $\left.0 \%\right)$ & 9,95 \\
\hline R14 (Cow manure20 ton ha $^{-1}+\mathrm{N}$ and $\left.\mathrm{K}\right)$ & 10,50 \\
\hline R15 (Cow manure20 ton $\mathrm{ha}^{-1}+$ NPK 50\% recommendation) & 10,25 \\
\hline
\end{tabular}

Table 6 shows the CEC value of residual soil amendmentbiochar rice husks and cow manure can both increase soil CEC which in the second growing season averaged a CEC value of 7,22 me $100 \mathrm{~g}^{-1}$, but an increase in CEC value is more likely to occur in residues of cow manure, although not significant. This happens allegedly the type of soil amendment that is applied does not directly have an effect in the soil, but it takes a long time to decompose in the soil. As stated by Laird (2008), the high resistance of biochar in the soil is that it can reach 1000 years to decompose.

Some of the results of previous studies such as Gautamet al (2017) said after the application of biochar and manure there was a slight increase in the content of CEC but without statistical differences. Furthermore, in the study of Herlambanget al (2019) also said cow manure can increase CEC within 2 months of the incubation period, because it is biodegradable and contains more cations. Although the value has increased in this third planting season, the

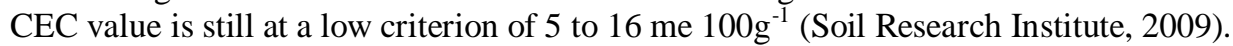

\section{Soil C:}

N Ratio:

Soil C:N ratio is the ratio between C-organic and total Nitrogen content of the soil. Low value of this ratio means decompositition of organic matter run fast or has entered a further phase, and vice versa. Table 7 shows the average 
value of $\mathrm{C}: \mathrm{N}$ ratio. It can be seen that soil $\mathrm{C}: \mathrm{N}$ ratio of the residues of several soil amendments addition did not show significant differences between treatments.

Table 7:- Average Ratio C:N effects of Soil amendment Residues at the Third Planting Period.

\begin{tabular}{|c|c|}
\hline Treatment & Ratio C:N(\%) \\
\hline R1 (Control (NPK $0 \%)$ ) & 7,75 \\
\hline $\mathrm{R} 2($ Control $(\mathrm{N}$ and $\mathrm{K}))$ & 8,05 \\
\hline R3 (Control (NPK $50 \%$ recommendation)) & 7,45 \\
\hline $\mathrm{R} 4$ (Biochar rice husk10 ton $\mathrm{ha}^{-1}+\mathrm{NPK} 0 \%$ ) & 7,04 \\
\hline $\mathrm{R} 5$ (Biochar rice husk10 ton $\mathrm{ha}^{-1}+\mathrm{N}$ and $\left.\mathrm{K}\right)$ & 6,12 \\
\hline R6 (Biochar rice husk10 ton $\mathrm{ha}^{-1}+$ NPK $50 \%$ recommendation) & 5,82 \\
\hline R7 (Biochar rice husk 5 ton ha $^{-1}+$ NPK $\left.0 \%\right)$ & 7,21 \\
\hline $\mathrm{R} 8\left(\right.$ Biochar rice husk 5 ton $\mathrm{ha}^{-1}+\mathrm{N}$ and $\left.\mathrm{K}\right)$ & 8,36 \\
\hline R9 (Biochar rice husk 5 ton ha $^{-1}+$ NPK $50 \%$ recommendation) & 6,93 \\
\hline R10 (Cow manure10 ton ha $^{-1}+$ NPK $\left.0 \%\right)$ & 7,46 \\
\hline R11 (Cow manure10 ton $\mathrm{ha}^{-1}+\mathrm{N}$ and $\left.\mathrm{K}\right)$ & 8,47 \\
\hline R12 (Cow manure10 ton ha $^{-1}+$ NPK $50 \%$ recommendation) & 9,40 \\
\hline R13 (Cow manure20 ton ha $^{-1}+$ NPK $0 \%$ ) & 8,74 \\
\hline R14 (Cow manure20 ton ha $^{-1}+\mathrm{N}$ and $\left.\mathrm{K}\right)$ & 8,18 \\
\hline R15 (Cow manure20 ton $\mathrm{ha}^{-1}+$ NPK $50 \%$ recommendation) & 8,35 \\
\hline
\end{tabular}

Table 7 shows soil $\mathrm{C}: \mathrm{N}$ ratio tends to be high in residue of cow manure increased dose from $2,5 \mathrm{t} \mathrm{ha}^{-1}$ to $10 \mathrm{t} \mathrm{ha}^{-1}$ combined with NPK $50 \%$ recommendation, with the value of 9,40\%. Whereas C:N ratio tends to be low in residue of rice husk biochar increased dose from $2,5 \mathrm{t} \mathrm{ha}^{-1}$ to $10 \mathrm{t} \mathrm{ha}^{-1}$ combined with NPK $50 \%$ recommendation, with the value of $5,82 \%$.

Based on table 7, C:N values of the treatments residue were categorized as low. Organic matters with low $\mathrm{C}: \mathrm{N}$ ratio value tend to be decomposed faster than the high value. It is expected can improve soil chemical properties and increase P uptake (Fikdalillahet al., 2016).

\section{Yield Potential of Soybeans:}

The results showed that the residual soil amendment did not significantly affect the yield potential of soybeans. The average yield potential of soybean plants can be seen in Table 8.

Table 8:- Average Yield Potential effects of Soil amendment Residues at the Third Planting Period.

\begin{tabular}{|c|c|}
\hline Treatment & Yield Potential (ton ha ${ }^{-1}$ ) \\
\hline R1 (Control (NPK $0 \%)$ ) & 0,33 \\
\hline $\mathrm{R} 2(\mathrm{Control}(\mathrm{N}$ and $\mathrm{K}))$ & 0,33 \\
\hline R3 (Control (NPK $50 \%$ recommendation)) & 0,45 \\
\hline R4 (Biochar rice husk10 ton $\mathrm{ha}^{-1}+\mathrm{NPK} 0 \%$ ) & 0,49 \\
\hline $\mathrm{R} 5\left(\right.$ Biochar rice husk10 ton $\mathrm{ha}^{-1}+\mathrm{N}$ and $\left.\mathrm{K}\right)$ & 0,32 \\
\hline R6 (Biochar rice husk10 ton $\mathrm{ha}^{-1}+$ NPK $50 \%$ recommendation) & 0,37 \\
\hline R7 (Biochar rice husk 5 ton ha $^{-1}+$ NPK $\left.0 \%\right)$ & 0,30 \\
\hline R8 (Biochar rice husk 5 ton ha $^{-1}+\mathrm{N}$ and $\mathrm{K}$ ) & 0,25 \\
\hline R9 (Biochar rice husk 5 ton ha $^{-1}+$ NPK $50 \%$ recommendation) & 0,36 \\
\hline R10 (Cow manure10 ton ha $^{-1}+$ NPK $\left.0 \%\right)$ & 0,34 \\
\hline R11 (Cow manure10 ton ha $^{-1}+\mathrm{N}$ and $\left.\mathrm{K}\right)$ & 0,31 \\
\hline R12 (Cow manure10 ton ha $^{-1}+$ NPK $50 \%$ recommendation) & 0,27 \\
\hline R13 (Cow manure20 ton ha $^{-1}+$ NPK $\left.0 \%\right)$ & 0,27 \\
\hline R14 (Cow manure20 ton $\mathrm{ha}^{-1}+\mathrm{N}$ and $\left.\mathrm{K}\right)$ & 0,60 \\
\hline R15 (Cow manure20 ton ha $^{-1}+$ NPK 50\% recommendation) & 0,59 \\
\hline
\end{tabular}


Table 8 shows that the potential yield of soybean plants due to soil amendment residues tends to be higher in cow manure residues of 20 tons ha ${ }^{-1}+\mathrm{N}$ and $\mathrm{K}$ (R14) than other treatments, the potential yield through these treatments is 0,60 tons $\mathrm{ha}^{-1}$. In Purba research (2018), the administration of cow manure significantly affected the total number of pods per plant. The highest number of total pods per plant was obtained from cow manure 30 tons ha $\mathrm{ha}^{-1}$.

\section{Protein:}

\section{Rough Protein Content of Soybean Seed:}

Soybean is the main source of protein, even soy is said to be a functional food source when viewed from the nutritional content of the seed. On a dry weight basis, soybeans contain about $40 \%$ protein, $20 \%$ oil, $35 \%$ soluble and insoluble carbohydrates and $5 \%$ ash (Liu, 2004). The results of the analysis of protein in soybean seed in the third planting season due to residues of soil amendment that have been given in the first and second growing seasons can be seen in Table 9 .

Table 9:- Average Protein in Soybean Seed effects of Soil amendment Residues at the Third Planting Period.

\begin{tabular}{|c|c|}
\hline Treatment & Protein $(\%)$ \\
\hline R1 (Control (NPK $0 \%)$ ) & 32,23 \\
\hline $\mathrm{R} 2(\mathrm{Control}(\mathrm{N}$ and $\mathrm{K}))$ & 30,49 \\
\hline R3 (Control (NPK $50 \%$ recommendation)) & 31,47 \\
\hline R4 (Biochar rice husk10 ton ha $^{-1}+$ NPK $0 \%$ ) & 30,53 \\
\hline R5 (Biochar rice husk10 ton $\mathrm{ha}^{-1}+\mathrm{N}$ and $\mathrm{K}$ ) & 29,73 \\
\hline R6 (Biochar rice husk10 ton $\mathrm{ha}^{-1}+\mathrm{NPK} 50 \%$ recommendation) & 30,44 \\
\hline R7 (Biochar rice husk 5 ton $\left.\mathrm{ha}^{-1}+\mathrm{NPK} 0 \%\right)$ & 29,79 \\
\hline $\mathrm{R} 8\left(\right.$ Biochar rice husk 5 ton $\mathrm{ha}^{-1}+\mathrm{N}$ and $\left.\mathrm{K}\right)$ & 30,51 \\
\hline R9 (Biochar rice husk 5 ton $\mathrm{ha}^{-1}+\mathrm{NPK} 50 \%$ recommendation) & 29,32 \\
\hline R10 (Cow manure10 ton $\mathrm{ha}^{-1}+$ NPK $\left.0 \%\right)$ & 30,83 \\
\hline R11 (Cow manure10 ton $\mathrm{ha}^{-1}+\mathrm{N}$ and $\left.\mathrm{K}\right)$ & 29,19 \\
\hline R12 (Cow manure10 ton ha $^{-1}+$ NPK $50 \%$ recommendation) & 28,86 \\
\hline R13 (Cow manure20 ton ha $^{-1}+$ NPK $\left.0 \%\right)$ & 29,65 \\
\hline R14 (Cow manure20 ton $\mathrm{ha}^{-1}+\mathrm{N}$ and $\mathrm{K}$ ) & 29,35 \\
\hline R15 (Cow manure20 ton $\mathrm{ha}^{-1}+$ NPK 50\% recommendation) & 30,65 \\
\hline
\end{tabular}

Table 9 shows the value of crude protein in soybean seed from the residue of soil amendment administration in the first planting season was highest at R1, that is without giving soil amendment and fertilizer which was $32,2 \%$. The soybean variety used is Dena I, in general Dena I has a protein content of $36,7 \%$. The decrease in protein value is thought to be due to the shelf life, because after harvesting soybean seed are not directly analyzed, other than that it is suspected because the very low soil $\mathrm{N}$ content is a factor affecting the protein content. There is also no statistically significant difference from the residual soil amendment to the protein content of soybean seed.

Protein is a source of amino acids that contain elements $\mathrm{C}, \mathrm{H}, \mathrm{O}$ and $\mathrm{N}$, in addition, proteins also contain phosphorus and sulfur (Budianto, 2009). There are several elements present in the soil that can affect protein. High and low protein contained in Figure 8 can also be caused by the ability of plants to absorb elements that are in the soil and ascend to the seed of plants running slowly, especially soil amendment which is an organic material that requires a long time to be decomposed in the soil.The protein content of soybean seed is also influenced by the elements nitrogen and phosphorus, as explained by Mitsuhashiet al (2005) states the accumulation of protein in seed is determined by the adequacy of P plants. In addition, Motlaghet al (2012) also reported an increase in protein content also in line with the application of phosphorus fertilizer in the soil. Besides phosphorus, nitrogen also plays a role in influencing protein in soybean seed but its effect is not significant.

\section{Conclusion:-}

The conclusions of this study include:

1. Statistical test results can be concluded that there are significant differences in the third growing season due to soil amendment residues in the first and second growing seasons on soil $\mathrm{pH}$ and $\mathrm{P}$-available. 
2. Potential results show the residual soil amendment of cow manure 20 tons $^{-1} \mathrm{a}^{-1}$ tends to be higher than that of other soil amendment residues.

3. Statistical test results can be concluded that there are significant differences in the third growing season due to residual soil amendment in the first and second growing seasons in the protein content of soybean seed.

\section{References:-}

1. Budianto A. K. 2009. Food, Nutrition and Human Development in Indonesia: The Basics of Nutrition, Malang: UMM Press 1-16.

2. El-Beshbeshy, T., N.A. El-Kader, R.E. Shal and N. Khalafallah. 2019. Impacts of biochar application on soil fertility, plant nutrients uptake and maize (Zea mays L.) yield in saline sodic soil. Arabian Journal of Geosciences. 12: 719.

3. Fathul, F., Liman, N. Purwaningsih and S. Tantalo. 2014. Feed Knowledge and Ration Formulation. Textbooks. Department of Animal Husbandry. Faculty of Agriculture. Lampung.

4. Fikdalillah, M. Basir, and I. Wahyudi. 2016. The Effect of Giving Cow Manure on Phosphorus Uptake and Yield of White Mustard (Brassica pekinensis) on EntisolSidera. e-J. Agrotekbis 4 (5): 491-499Gani, A. 2009. Food Crop Science and Technology (ISSN 1907-4263) Vol. 4 No. 1, July 2009. p. 33-48.

5. Gani, A. 2009. Food Crop Science and Technology (ISSN 1907-4263) Vol.4 No.1, July 2009. p. 33-48

6. Gautam, D.K., R.M, Bajracharya, and B.K. Sitaula. 2017. Effects of Biochar and Farm Yard Manure on Soil Properties and Crop Growth in an Agroforestry Systemin the Himalaya. Journal Sustainable Agriculture Research 6(4) Canadian Centre of Science and Education. 6(4): 74.

7. Hardjowigeno, S. 2003. Soil Classification and Pedogenesis. Jakarta: Pressindo Academics. 250 p.

8. Hasanuddin, A., J. R. Hidajat, and S. Patohardjono. 2005. Potential legume research program policy. In Partohardjono (editor). Analysis and Policy Options for Research and Development of Food Crops. Monograph No. 2. Bogor Food Crop Research and Development Center: 64-77.

9. Herlambang, S., AZ.P. Budi S, H.T. Sutiono, and S. Rina N. 2019. Application of coconut biochar and organic materials to improve soil environmental. IOP Conf. Series: Earth and Environmental Science. 1755-1315.

10. Kartika, K. , B. Lakitan, A. Wijaya, S. Kadir, L. I. Widuri, E. Siaga, and M. Meihana. 2018. Effects of particle size and application rate of rice-husk biochar on chemical properties of tropical wetland soil, rice growth and yield. Australian Journal and Crop Science. 12 (05):817-826.

11. Laird, D.A. 2008. The charcoal vision: a win-win-win scenario for simultaneously producing bioenergy, permanently sequestering carbon, while improving soil and water quality. Agronomy Journal100: 178- 181.

12. Lakitan, B. 2012. Fundamentals of Plant Physiology. PT Raja GrafindoPersada. Jakarta.

13. Liu, K. 2004. Soybeans as Functional Foods and Ingredients. AOCS Publishing, USA.

14. Liu, S., J. Meng, L. Jiang, X.Yang, Y. Lan, X. Cheng, and W.Chen. 2017. Rice Husk Biochar Impacts Soil Phosphorus Availability, Phosphatase Activities and Bacterial Community Characteristics in Three Different Soil Types. Applied Soil Ecology. Vol.116, P. 12-22. Elsevier.

15. Mi, W., Y. Sun, S. Xiaa, H. Zhao, W. Mi, P. C. Brookes, Y. Liu, and L. Wu, 2018. Effect of inorganic fertilizers with organic amendments on soil chemical properties and rice yield in a low-productivity paddy soil. Geoderma 320 (2018) 23-29.

16. Mitsuhashi, N., M. Ohnishi, Y. Sekiguchi, K. Y.U. Kwon, Y.T. Chang, S.K. Chung, Y. Inoue, R.J. Reid, H. Yagisawa, T. Mimura. 2005. Phytic acid synthesis and vacuolar accumulation in suspension-cultured cells of Catharanthusroseusinduced by high concentration of inorganic phosphate and cations. Plant Physiol. 138:16071614.

17. Motlagh, S.M., P. Alireza, D. Babak. 2012. Effect of biological phosphorus and irigation disruption on biomass, seed yield and protein content of canola (Brassica napusL). Int. Res. J. Appl. Basic. Sci. 3:961-967.

18. Muliawan, N.R.E., J. Sampurno J, M. I. Jumaranga. 2016. Identification of Salinity Value in Agricultural Land in Jungkat District Based on Electrical Conductivity Method. Prisma Physics, Vol. IV, No. 02 (2016), Hal. 6972.

19. Mulyani, A. and F. Agus. 2006. Land Potential Supports Agricultural Revitalization. Proceedings of the Multifunction Seminar and Revitalization of Agriculture 27-28 June 2006. Center for Research and Development of Land Resources. Bogor.

20. Nisa, K. 2010. Effect of NPK and Biochar Fertilization on Soil Chemical Properties, Nutrient Absorption, and Yield of Rice Field Crops. Thesis. Kualia University. Banda Aceh.

21. Pandit, N.R., J. Mulder., S.E. Hale., A.R. Zimmerman., B.H. Pandit, and G. Cornelissen. 2018. Multi-year Doeble Cropping Biochar Field Trials in Nepal: Finding the Optimal Biochar Dose Throgh Agronomic Trials and Cost-Benefit Analysis. Journal Science of the Total Environment 637-638: 1333-1341. 
22. Purba, J.H., I.P. Parmila, K.K. Sari. 2018. Effect of Sapid Manure and Planting Distance on Growth and Yield (Glycine max L. Merrill) of Edamame Varieties. Agro Bali (Agricultural Journal). Vol. 1 No. 2: 69-81.

23. Rahmi, A. and Biantary, P. M. 2014. Characteristics of Soil Chemical Properties and Soil Fertility Status of Land and Farming Land in Several Villages in West Kutai District. Ziraa'ah. 39 (1). 30-36.

24. Salawati, M. Basir, I. Kadekoh, A. R. Thaha. 2016. Potential of Biochar Rice Husk Against Changes in pH, CEC, Organic C and P Available in Insepticol Paddy Soils. J. Agroland 23 (2): $101-109$.

25. Soil Research Institute. 2009. Chemical Analysis of Soil, Plants, Water and Fertilizers. Soil Research Institute, Bogor.

26. Soil Survey Staff. 2014. Keys to Soil Taxonomy. United States Departement of Agriculture. Natural resources Concervation Services. USA.

27. Singh, C., S. Tiwari., V.K. Gupta.,and J.S. Singh. 2018. The Effect of Rice Husk Biochar on Soil Nutrient Status, Microbial Biomass and Paddy Productivity of Nutrient Poor Agriculture Soils. Journal CATENA 171: 485-493.

28. Syamsuddin, S. Takdir and A. Hasan. 2016. The Correlation between Giving Cow Cages Fertilizer with Increased Protein Content and Coarse Fiber of the Legume Clitoriaternatea as Animal Feed Forage. Journal of Tropical Animal Science and Technology (JITRO) VOL. 3 NO. 2.

29. Tambunan, W. A. 2008. Study of Physical and Chemical Properties of Soils in Relation to Production of Palm Oil (ElaeisguineensisJacq.) In the PTPN II Oil Palm Plantation. Thesis. University of Northern Sumatra. Field.

30. Wilson, J. R. dan M. M. Ludlow. 1990. The environment and potensial growth of herbage under plantations.Proceeding of workshop, Sanur, Bali, Indonesia. 10--24.

31. Xie, T., B.Y. Sadasivam, K.R. Reddy, C. Wang. 2016. Review of The Effects of Biochar Amendment on Soil Properties and Carbon Sequestration. Journal of Hazardous, Toxic and Radioactive Waste. Vol: 20 (1).

32. Yunilasari, M. 2019. Effect of Biochar Dose and Manure on the Chemical Properties of Entisols and the Result of Peanut (Arachishypogeae L.) Second Planting Season. Thesis Master Program in Conservation of Land Resources, Postgraduate Program, Syiah Kuala University.

33. Zhu, Q., X. Peng, T. Huang., Z. Xie and N.M Holden. 2014. Effect of biochar addition on maize growth and nitrogen use efficiency in Acid Red Soil. Pedospere 24 (6): 699-708. 